\title{
The Impact of COVID-19 on Private Enterprises and Informal Economy Unities in Togo
}

\author{
Banyokme F. Badjassilona ${ }^{1}$, Kossi Ayenagbo ${ }^{1 *}$, Seydi A. Dieng² \\ ${ }^{1}$ Departement d'Economie, FaSEG, Universite de Kara, Kara, Togo \\ ${ }^{2}$ Université Cheikh Anta, Diop, Dakar, Sénégal \\ Email: *ayenagbo@yahoo.fr
}

How to cite this paper: Badjassilona, B. F., Ayenagbo, K., \& Dieng, S. A. (2021). The Impact of COVID-19 on Private Enterprises and Informal Economy Unities in Togo. Open Journal of Social Sciences, 9, 347-374. https://doi.org/10.4236/jss.2021.95018

Received: April 10, 2021

Accepted: May 15, 2021

Published: May 18, 2021

Copyright (c) 2021 by author(s) and Scientific Research Publishing Inc. This work is licensed under the Creative Commons Attribution International License (CC BY 4.0).

http://creativecommons.org/licenses/by/4.0/

(c) (i) Open Access

\begin{abstract}
COVID-19, far from being a health crisis, has turned into an economic and social crisis, leading to the closure of businesses around the world. Togolese businesses, both formal and informal, have suffered in one way or another. The objective of this study is to highlight the impact of this pandemic on private enterprises and informal economy unities in Togo. The database of the General Office of Work in Togo (DGT, 2020) was subjected to a descriptive statistical analysis. After documentary research, we have used the SPSS software to analyse the variables taking into account. Word and Excel software were also used to format the tables and generate some figures. The results revealed that, about $96.80 \%$ of the unities were impacted by the crisis and 1105 jobs were lost in some unities. The results showed also that the occurrence of collective and individual conflicts in some unities is about $3.91 \%$ due to the health crisis.
\end{abstract}

\section{Keywords}

COVID-19, Private Enterprises, Informal Economy Unities, Labour Relations, Togo

\section{Introduction}

Most of the African Economy is Informal (ILO, 2020a). The private enterprises are the entities that operate under the ownership and management of individuals that freely decided to develop a given business idea. Its freedom from government intervention is what makes it different from a government institution. The informal sector or the informal economy unities can be defined as all production unities (PIUs) without an administrative registration number and/or formal written accounts. In Africa, private entreprises and informal sector contribute to 
an increase in GDP of those countries. The African Development Bank (AfDB) highlights strong growth performance of economic activities on the African continent in recent years. Indeed, the continent's gross domestic product (GDP) growth rate was estimated at $3.4 \%$ for the year 2019 , slightly higher than the global average of $3.0 \%$ and well above that of advanced economies which were $1.7 \%$ (AfDB, 2020). Coronavirus 2019, an infectious disease caused by the SARS-CoV-2 strain of coronavirus, however, appears to threaten more than a decade of economic and human development gains on a continental and global scale.

In March, 2020, the World Health Organization (WHO) declared this disease of COVID-19 "pandemic" worldwide. This virus has spread very quickly in 193 countries and territories and is currently present on all continents in a heterogeneous way like 29,042,231 cases in America, 19,651,559 cases in Europe, 16,345,907 cases in Asia, 2,273,940 cases in Africa and 52,713 cases in Oceania (https://www.ecdc.europa.eu/en, 2020).

Nearly a year after the start of the pandemic, Africa with 59,746 deaths could consider itself lucky given the predictions against it at the beginning of the spread of COVID-19. According to international observers, the economic downturn caused by this virus has had a threefold effect on the global economy: 1) direct impact on global production volumes; 2) disruptions and alterations in supply and distribution chains; and 3) financial impact on entreprises and stock markets (DORSAN, 2020).

In Togo, the first case of COVID-19 was announced on March 6, 2020 and a state of health emergency was declared on April 1, 2020 leading to the closure of borders from March to August 2020. According to the World Bank Group (WB) report on the economic situation in Togo, "the COVID-19 pandemic has had a significant negative effect on the private sector" and "the immediate impact of the crisis has been mainly in the form of temporary closures, lay-offs or unpaid leaves of employees and a significant decline in sales. The average decline in the level of sales is estimated at 51.3 percent in June 2020 compared to the previous month" (WB, 2020a).

The same report states that the sectors most affected by the pandemic as a result of government restrictions are tourism, transport and logistics, manufacturing, agriculture, and agribusiness. SMEs are the most affected, as access to financing has become more difficult (for medium and long term financing) and costly (for short term financing), the report reveals. Knowing that the Togolese economy is largely informal (IMF, 2017; INSEED, 2019), the severe restrictions taken to fight the spread of the pandemic could prove harmful to the actors of this sector, which absorbs almost all of the active population, including all sectors of activity (INSEED, 2019). The IMF's global outlook highlights the fact that "low-skilled workers without the ability to work from home" would have "suffered the most from the labour market shock" (IMF, 2020a).

The studies conducted in Togo since the announcement of the first case of COVID-19, ranging from those concerned with forecasting the spread of the 
pandemic to those based on various scenarios in order to identify the direct and indirect effects on the Togolese economy (UNDP, 2020), show that these studies have had as their main survey unities in Lomé, the capital, and/or private sector entreprises (CCIT, 2020) in order to highlight the impact of COVID-19 on the entreprises surveyed and to make recommendations to the government and entreprises (CNP, 2020) without necessarily broadening the scope of the study to the national level or doing so based on macroeconomic modeling (UNDP, 2020).

The general objective of our research is to analyze the impact of COVID-19 on private enterprises and informal economy unities in Togo. A survey was recently conducted by the General Directorate of Labour (DGT) in order to evaluate the prevention and control mechanisms of COVID-19 in the workplace. Specifically, this study will analyze the impact of this pandemic on jobs (Bentone, Cazorla, \& Hemdane, 2019), in the unities and on labour relations in private entreprises and unities of the informal economy.

\section{Literature Review of Impacts of COVID-19 on the Global Economy and on the Private Entreprises and Informal Economy Unities}

The economic literature is abundant on this subject. Our bibliographic synthesis will thus be based on the main currents of economic thought concerning the labour market and on recent scientific writings in order to shed light on the foundations of this market, which has been the subject of criticism over time.

The impact of the disease on society and the economy can be seen in the lockdown of cities around the world, work mobility restrictions, travel bans, airline suspensions, and most importantly, the downturn in the economy. According to (ILO, 2020a), the COVID-19 pandemic has hit Africa through its informal economy at the time when the region is experiencing modest economic growth. African Economic Outlook (AEO) observes that Africa's economic growth remained stable in 2019 at 3.4 percent and is on course to pick up to 3.9 percent in 2020 and 4.1 percent in 2021. With this pandemic and according to AEO, the challenge is thus twofold to raise the current growth path and to increase the efficiency of growth in generating employment by the global economy and especially by the informal economy. In view of this situation, it is no wonder that the biggest fear among African governments today is the loss in this momentum as they struggle to mitigate the COVID-19 pandemic.

The pandemic like the COVID-19 outbreak is expected to have a major impact on global GDP growth (Word Economic, 2020). As a result of the global COVID-19 epidemic, the global GDP of all the countries is expected to be affected by $2.3 \%$ to $4.8 \%$ (AfDB, 2020). In addition, it has also been predicted that the current pandemic outbreak could result in a 5\% - 15\% decrease in global foreign direct investment (UNCTAD, 2020b). Furthermore, according to the UNCTAD report, the world needs a support package of up to $\$ 2.5$ trillion to cope with the damage (UNCTAD, 2020a). Thus, based on these statistics, the 
current global crisis is likely to be worse than the 2008 crisis (UNCTAD, 2020a) and damage the development of the private and informal sector.

In addition, according to the International Labour Organization (ILO), nearly 25 million people worldwide could lose their jobs (up to $\$ 3.4$ trillion in lost worker income) (ILO, 2020c). A more recent ILO report shows that lockout measures (total or partial) influence $81 \%$ (about 2.7 billion workers) of all global workers (ILO, 2020b). This pandemic is the worst global crisis since World War II (ILO, 2020b). The United States is estimated to lose three million jobs by mid-summer 2020, the trend in Europe and other parts of the world will be similar (Siddiqui, 2020). According to the ILO, the impact of COVID-19 on economic output in the accommodation and food services, real estate, wholesale and retail trade, and motor vehicle and motorcycle repair sectors is "high," while that of public services, public administration and defense, social activities, human health, and education is "low" (ILO, 2020a).

The pandemic of COVID-19 will have a more profound effect on private entreprises and informal economy, as it will be much more difficult for them to implement effective stimulus measures without facing binding exchange rate constraints (UNCTAD, 2020a). The most vulnerable countries are those with weak health infrastructure, heavy reliance on the trade and tourism sectors, high levels of debt, and reliance on volatile capital flows (WB, 2020a). Controlling the COVID-19 epidemic will boost the economy, but the risk of continued financial stress is very high even after 2020 (WB, 2020a). In addition, it has also been estimated that poverty is likely to increase by approximately 11 million people (WB, 2020a). While the economic impact of the epidemic will continue and be increasingly unpredictable, it is clear that developing economies will get worse before they get better (UNCTAD, 2020a). According to the United Nations Development Programme (UNDP), income losses in developing countries are expected to exceed $\$ 220$ billion (UNDP, 2020). In addition, the World Bank predicted in its recent report that South Asia could experience its worst economic performance in 40 years, with half of the countries falling into deep recession (WB, 2020b). COVID-19 generates the devastating impact of a health and economic crisis on those operating in the informal economy (ILO, 2020b).

\section{Hypotheses}

The hypotheses underlying our research are as follows:

1) The pandemic context led to the contraction of the workforce in enterprises and unities of the informal economy;

2) Labour relations in private firms and informal economy unities have deteriorated during the health crisis.

The contribution of this study to the economic literature on the subject is twofold. The first is that it focuses not only on private firms, but also on unities of the informal economy, commonly called informal production unities (IPU), which are the main providers of employment (INSEED, 2019) in Togo. Looking 
at the consequences of the pandemic on labour relations within the unities is a second major contribution, in contrast to previous studies (UNDP, 2020; CCIT, 2020; CNP, 2020) which were mainly interested in the impact on the functioning of enterprises and, by extension, on the employment situation in the private sector.

\section{Macroeconomic Framework before and during the Pandemic of COVID-19 Crisis in Togo}

Thanks to the implementation of various development policies that followed the "planning revival", the Togolese economy has remained relatively robust over the last decade. Indeed, the resumption of cooperation with technical and financial partners in 2008 made it possible to draw up Poverty Reduction Strategy Papers (PRSPs) covering the period 2008-2011, a strategy for accelerated growth and employment promotion (SCAPE 2013-2017) and the current planning framework: the National development programm (NDP 2018-2022). Recent gains have been favorable to the decline in the poverty rate over the $2011-2017$ period from $58.7 \%$ in 2011 to $53.5 \%$ in 2017 (INSEED, UNDP, 2017).

With an average real GDP growth rate (2015-2019) of 5.2\%, the growth of the Togolese economy remained below the average growth rate of WAEMU countries, which was 6.1\% in 2019 (WAEMU, 2020), but above that of Sub-Saharan African countries (WB, 2020a) over the same period. Despite a drop in this growth rate to $4.4 \%$ in 2017, it picked up again and reached $5.3 \%$ in 2019 (Figure 1) with the implementation of a very ambitious National development programm (2018-2022) driven by public and private investments and improved agricultural productivity. This dynamism of the Togolese economy has been driven over the past two years by the performance of the market tertiary sector and the non-market branches, whose contribution to real GDP in 2018 was 2.2 points and 2.6 points respectively. The services sector remains the main driver of growth due to increasing port and airport traffic. However, it should be noted

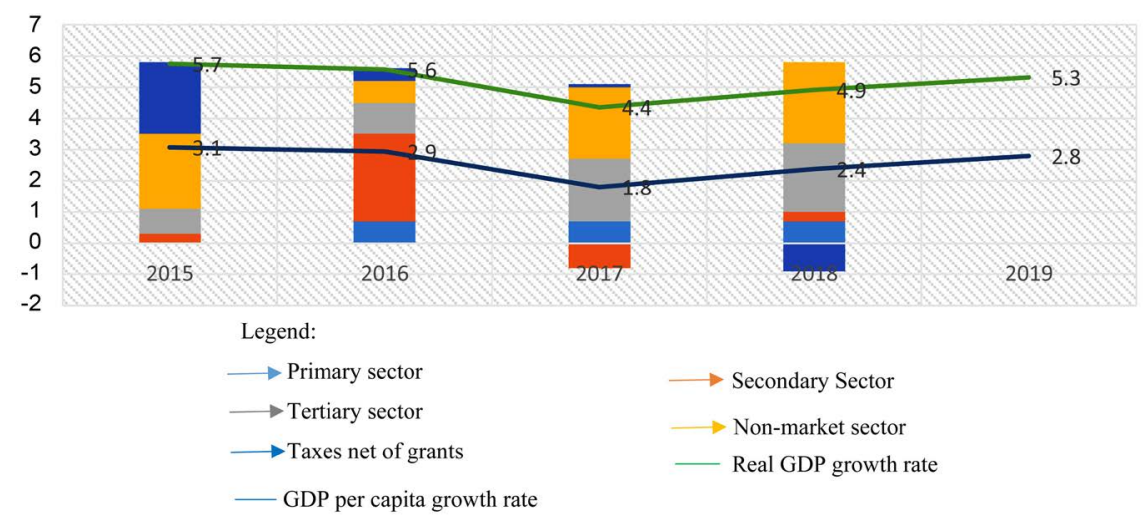

Figure 1. Structure of the Togolese economy. Source: Author based on World Development Indicators (WDI) database and 2019 macroeconomic framework_GDP Committee_Togo. 
that GDP per capita growth remained low with an average of $2.6 \%$ over the 2015-2019 period (WDI, 2020).

According to the recent WB (2020a) report in Togo, the dynamic growth of the Togolese economy has been made possible by public investment in connection with the construction of new road and port infrastructure; a rebound in private investment; the dynamism of the agricultural sector and the expansion of the industrial sector. The COVID-19 pandemic "shakes all macro- and micro-economic fundamentals and upsets all estimates of economic growth", according to the WAEMU Regional Consular Chamber's (2020) report on the impact of the COVID-19 pandemic on the zone's private sector. Logically, therefore, Togo could be expected to have a year with a drop in all the macroeconomic indicators that had seen significant progress in recent years. According to recent estimates, Togo's GDP growth rate could stabilize at 1.3\% (WAEMU, 2020). The secondary and tertiary sectors would be the most affected due to the slowdown in the extractive industries, construction, trade, hotels, bars, restaurants, and transportation.

The macroeconomic indicators relating to the convergence criteria (Table 1) for WAEMU member states indicate, for the most part, a good performance by Togo over the period 2015-2019. For the year 2019, Togo is one of the countries that met four (4) out of five (5) criteria (Mali and Togo) and the only one that came close to meeting the "tax pressure rate" criterion (WAEMU, 2020).

Indeed, with respect to the top-ranking criteria, inflation was kept under control over the 2015-2019 period, remaining below the WAEMU standard (3\%) due to "an abundant supply of food products reflecting an increase in agricultural productivity on the one hand and a decline in communication costs on the other" (WB, 2020a) the overall budget deficit (including grants) has improved over the past three years, thanks in particular to expenditure control and strong

Table 1. Evolution of macroeconomic indicators relating to the convergence criteria.

\begin{tabular}{|c|c|c|c|c|c|c|}
\hline Years & 2015 & 2016 & 2017 & 2018 & 2019 & 2020 \\
\hline \multicolumn{7}{|c|}{ First rank convergence criteria } \\
\hline $\begin{array}{l}\text { Overall budget balance including grants } \\
\text { ( } \% \text { of GDP) }\end{array}$ & -6.3 & -8.1 & -0.3 & -0.8 & -1.1 & -5.0 \\
\hline Annual inflation rate (\%) & 1.8 & 0.9 & -0.2 & 0.9 & 0.7 & 3.0 \\
\hline Outstanding public debt (\% of GDP) & 70.3 & 76.6 & 72.2 & 73.5 & 68.3 & 66.9 \\
\hline \multicolumn{7}{|c|}{ Second rank convergence criteria } \\
\hline Payroll over tax revenue (\%) & 33.2 & 32.1 & 34.2 & 36.6 & 34.3 & 41.2 \\
\hline Tax revenues to GDP (\%) & 20.9 & 21.3 & 20.1 & 18.4 & 19.5 & 17.5 \\
\hline \multicolumn{7}{|c|}{ Other indicators } \\
\hline Trade balance FOB-FOB & -610.80 & -571.67 & -373.81 & -434.62 & -398.53 & -364.39 \\
\hline
\end{tabular}

Source: Author, constructed based from data in the annex to the WAEMU's semi-annual multilateral surveillance report, 2020 . 
revenue mobilization, especially tax revenue, due to the tax and customs administration reforms initiated by the Togolese Revenue Office (OTR); the outstanding public debt remained above the community standard (70\%) from 2015-2018 and has risen to $68.3 \%$ in 2019 , reflecting the government's efforts to reduce its level of indebtedness following the reforms carried out as part of the improvement of public finance management with the support of the IMF and the WB.

For the second-tier criteria: the criterion of the wage bill as a proportion of tax revenue was met over the period, with the exception of 2018, while the tax burden rate has remained below the norm (20\%) for the last two years.

Like most EU countries, Togo has a trade deficit, although this has improved in recent years. Exports of clinker (about 13\% of export earnings), phosphates (10\%), and cotton fiber are the three main export products, while imports are mainly consumer goods and capital goods. Exports and imports of goods for the year 2020 are expected to decline due to the contraction of global economic activity despite massive imports of medical materials and products dedicated to the fight against COVID-19.

Although the monthly inflation rate estimated by Trading Economics in September 2020 for Togo is equal to $2.9 \%$, the average annual inflation rate would be below 3\% (WAEMU, 2020). The overall budget deficit (including grants) will increase due to the decline in total revenue, mainly as a result of tax relief measures granted to businesses, and an increase in total expenditure as a result of the rise in public consumption (acquisition of health materials and equipment, cash transfers to vulnerable populations) as part of the fight against the COVID-19 pandemic. Donor grants and loans will increase to enable the country to respond to health emergencies. Tax revenues will logically decline as a result of tax relief measures granted to businesses and the wage bill will increase as a result of the strengthening of the health system and the payment of bonuses to health personnel announced by the Togolese government.

\section{Employment and Labour Situation in Togo before the Pandemic of COVID-19}

There are three main areas of employment in Togo. These are the agricultural sector, the informal sector and the modern sector (public and private). According to data from the 2010 general population and housing census (RGPH, 2010), the Togolese working population was estimated at 3,341,763. The results of the 2015 Unified Questionnaire of Basic Welfare Indicators (QUIBB) reveal that the agriculture, livestock and forestry branch employs more than the other branches (54.1\%) followed by trade (15.2\%).

The integrated Regional Survey on Employment and the Informal Sector (ERI-ESI) provides information on job opportunities in the Togolese labour market. Indeed, available jobs (employment/population ratio) represent $60.7 \%$ of the working age population (15 years or older) and own account workers and family workers (qualified as vulnerable workers) represent $74.7 \%$ of jobs (INSEED, 2019). 
Table 2 shows a decrease in the unemployment rate over the period 2011 to 2017 from $6.5 \%$ in 2011 to $3.4 \%$ in 2015 and to $3.9 \%$ in 2017 . This unemployment rate is rather high in the young population reaching $9.7 \%$ for those with an age between 15 and 24 years (year 2017). The unemployment rate is higher among men and in urban areas, regardless of the year of data collection. The unemployment rate for people with disabilities was estimated at $80 \%$ in 2014 (MTESS, 2014).

Despite this relatively low unemployment rate, which is lower than the reference rate of $5 \%$ set by the ILO as corresponding to a situation of full employment, the employment situation remains one of the major and current challenges for the Togolese government. Data on the underemployment rate reveal that this rate has been slightly increasing over the period 2011 to 2015 from $22.8 \%$ in 2011 to $24.9 \%$ in 2015 (INSEED, 2016). Urban dwellers (27.7\%) are the most affected by this situation as well as those between the ages of 30 and 49 (29.5\%). Job losses associated with the deterioration of working conditions due to the pandemic could increase the rate of underemployment (Table 2).

Despite policies to support and organize the informal sector, this sector is still the largest provider of employment in most Sub-Saharan African countries. In Togo, $87.9 \%$ of non-agricultural jobs are provided by the informal sector and this informality rate reaches $91.6 \%$ considering all sectors of activity (INSEED, 2019). The informal sector is estimated to contribute between 20 and $30 \%$ to the national GDP (IMF, 2017). Resilient in the face of previous economic crises, the informal sector was hit hard by the pandemic. Actors in this sector have had to resort to several approaches. As a result, thousands of people have been forced to reduce their working hours or stay at home without working and without the possibility of using alternative forms of work available to actors in the modern private and public sector, such as telecommuting, part-time work, early leave, etc.

The direct consequences of the pandemic on civil servants in the public administration are mainly on two levels: 1) the rearrangement of working hours during the curfew period and 2) the postponement to 2021 of the recruitment of

Table 2. Changes in the unemployment rate between 2011 and 2017.

\begin{tabular}{cccc}
\hline Unemployment rate & QUIBB 2011 & QUIBB 2015 & ERI-ESI 2017 \\
men & $5.2 \%$ & $4.0 \%$ & $5.0 \%$ \\
women & $8.0 \%$ & $2.7 \%$ & $2.9 \%$ \\
$15-$ 24 years old & $10.3 \%$ & $4.7 \%$ & $9.7 \%$ \\
$15-$ 35 years old & $8.3 \%$ & $4.0 \%$ & $6.8 \%(15-34$ years old $)$ \\
Urban & $11.5 \%$ & $6.2 \%$ & $6.3 \%$ \\
Rural & $3.4 \%$ & $1.3 \%$ & $2.0 \%$ \\
Whole country & $6.5 \%$ & $3.4 \%$ & $3.9 \%$
\end{tabular}

Source: QUIBB, 2011, QUIBB, 2015 and ERI-ESI, 2017. 
new civil servants in certain structures of the public administration. The structures in charge of promoting employment (the DGE) or producing statistics on the labour market (the employment observatory) have not produced any reports that highlight the proportion of jobs lost or created throughout the country in this crisis context. However, studies are being carried out.

The continued implementation of the national development programm, which relies on the dynamism of the Togolese private sector (MPDC, 2018), should eventually create decent jobs over the plan's implementation period and reduce unemployment and underemployment rates.

The ILO report, World Employment and Social Issues (ILO, 2019), states that "progress in reducing unemployment worldwide is not systematically accompanied by improvements in the quality of employment. In Togo, the labour inspection and administration system through its labour inspection services are responsible for ensuring the application of labour legislation in terms of fundamental principles and rights at work (PDFT), occupational safety and health (OSH) and social dialogue.

To date, Togo has ratified twenty-eight (28) conventions of which twenty-four (24) are in force, two (2) conventions have been denounced and two (2) instruments have been repealed. It has also made efforts to achieve MDG 8 "economic growth and decent work". This is reflected mainly in the development of the National Labour Policy (NTP), the Decent Work Country Programs (2010-2015 and 2019-2022) and the tripartism advocated by the national authorities.

In Togo, the minimum wage is set at 35,000 CFA francs (Order No.

$003 / 2012 /$ MTSS/DGTLS on the revision of guaranteed minimum wages of May 1,2012 ) and the weekly working time in all non-agricultural enterprises is set at 40 hours (Article 142 of the Togolese Labour Code, 2006). Labour productivity (real GDP in relation to the number of workers) increased significantly over the 2010-2015 period from 592,221 in 2010 to 763,824 in 2015 (ANPE/Togo, 2019) while the child labour situation is still a concern (1.9\% of children aged 10-14 years were in a work situation in 2017 (INSEED, 2019).

The COVID-19 crisis seems to have devastating consequences on millions of workers already in vulnerable situations (especially informal sector workers, migrants, children whose parents have lost their jobs) jeopardizing the respect of their fundamental principles and rights at work (ILO, 2020c). According to the ILO, these four PDFTs "also form the foundation for rebuilding a better and fairer world of work in the aftermath of the health crisis" (ILO, 2020c).

The contributory social protection system in Togo comprises three main schemes: the general social security scheme managed by the National Social Security Fund (CNSS); the civil and military pension scheme managed by the Togo Retirement Fund (CRT); and the compulsory health insurance scheme managed by the National Health Insurance Institute (INAM).

In addition to these schemes, there are social mutuals and private insurances, which are mainly aimed at employees of entreprises in the formal sector. Faced 
with the upheaval in the world of work in this context of crisis, communication sessions for workers and employers in Togo have made it possible to raise awareness about the risks of contamination in the workplace and the barrier measures to be adopted. An employer's guide on the management of workplaces during a period of COVID-19 was also popularized by the National Council of Employers (CNP), not to mention the guide on alternative forms of work in times of crisis that has been developed.

As regards social dialogue, i.e., all of the mechanisms within which the interests of employees, employers and the government are confronted, this aspect has seen notable progress in recent years (ANPE/Togo, 2019). In the face of the crisis, however, the rights to freedom of association and collective bargaining are being undermined by broader government measures.

A new labour code was developed and adopted on December 29, 2020. This process aims to have a labour code that is adapted to changes in the labour market and takes into account new forms of work and current realities.

\section{Outlook of Health Crises and Their Impact on the Labour Market}

The public and industrial sectors were the ones that were most affected during the period of pandemic. One of the epidemics of modern times is HIV/AIDS. Identified since the early 1980 's, the statistics regarding this epidemic are equally alarming for the world of work as they are for people living with HIV/AIDS. UNAIDS (2020) counts 75.7 million people who have been infected with HIV since the beginning of the epidemic and 32.7 million people who have died from the disease (UNAIDS, 2020). At the time when HIV/AIDS was devastating and antiretroviral treatment was not available, its impact at the micro level was mainly manifested by increased absenteeism of infected individuals, decreased productivity, and termination or renewal of employment by the employer (UNAIDS, 2002). This has had impact on the activities of entreprises and has changed the work environment, leading to discrimination and a considerable impact on working relations within entreprises. With advances in medicine and the efforts of governments and international organizations (ILO, UNAIDS, etc.), HIV/AIDS is no longer a barrier to entering and remaining in the labour market.

The Ebola virus caused a series of smaller epidemics in Central Africa (in the Democratic Republic of Congo, Sudan, Congo, Uganda, Gabon) from 1976 to 2012. The 2014 outbreak, on the other hand, caused "global epidemic concern" due to its rapid spread and high case fatality rate in some West African countries. However, this virus was contained to a few countries and did not take on the appearance of previous epidemics and pandemics. The countries most affected by this epidemic (2014-2016) were: Guinea, Liberia and Sierra Leone. It has impacted the economy, reduced GDP and limited employment opportunities in these countries (UNDP, 2014). The Economic Commission for Africa (ECA, 2015) admits that the sectors mainly affected by the downturn due to the 
epidemic are trade, mining, agriculture and services with "informal cross-border commercial activities that were affected by $50 \%$ in Guinea and $70 \%$ in Liberia". Massive business closures and layoffs have been observed in all the hard-hit countries, and the reduction in employment has had a domino effect on wages, incomes and the purchasing power of economic agents.

Avian flu epidemics have been mentioned throughout human history. The influenza virus has caused a series of mass deaths in poultry or pigeons mainly. However, a form of this virus that appeared in 2004 (H5N1) proved dangerous because of its "transmissibility" to humans, earning it the name "avian influenza" or "fowl plague" and resulting in 573 cases of human infections with a case fatality rate of $58.6 \%$ (Morin, 2012). The indirect consequences in West Africa of avian influenza have been job losses due to layoffs or technical unemployment observed on affected farms; reduced wages; and reduced staffing on unaffected farms (ECOWAS et al., 2006). The poultry catering and trade sectors were also affected by job losses resulting from the decline in "poultry demand.

The health crises that have plagued humankind at different times have undoubtedly had a negative impact on the global economy and changed the labour market in many ways. The Black Death contributed to the increase in income of European workers of the time, who had bargaining power against landowners who were desperately short of labour (The New Economist, 2020). A similar situation was observed in the American states after the Spanish flu epidemic. Analyses by Brainerd and Siegler (2003) based on a range of demographic and economic factors reveal that one additional death per thousand people translated into an annual increase in real income of at least 0.15 percentage points in the ten years following the epidemic. With a case fatality rate of $2.30 \%$ (John Hopkins University, 2020) COVID-19 appears to be less lethal than the major epidemics and pandemics discussed in this literature review. Indeed, the case fatality rate of the Ebola virus (2014) ranged from 39.14\% in Sierra Leone to $64.59 \%$ in Guinea, while that of the Spanish flu was estimated at nearly $20 \%$ according to Taubenberger \& Morens (2006) and Johnson \& Mueller (2002).

\section{The Labour Market and the Pandemic of COVID-19}

According to international organizations such as the IMF and the World Bank, COVID-19, far from being a health crisis, is destabilizing the global economy and impacting most economic sectors, leading to a global recession and millions of people in poverty (WB, 2020b; IMF, 2020b; IMF, 2020a). GDP growth is projected to decline by $4.9 \%$ (IMF, 2020a), even more than the decline experienced in 2009 as a result of the financial and economic crisis.

The drop in activity in China following the outbreak of COVID-19 cases quickly impacted the US, the euro zone and Africa, one of the country's leading exporters, reminding us once again of China's place in the global supply chain.

The border closures, travel bans, quarantine measures and other responses to COVID-19 have not been without consequences for the world of work, especial- 
ly for workers who have been unable to get to their place of work, especially those in the informal sector who have no social protection in times of crisis (http://www.ilo.org/: COVID-19 crisis, World of work and industrial economy).

Nearly four months after the onset of the pandemic in China (March 2020), the ILO Observatory sounded the alarm with a "preliminary assessment of the possible impact of COVID-19 on the world of work" and highlights that the crisis has "turned into a shock to the economy and labour market" (ILO, 2020d). The observatory (ILO, 2020b) already estimated in April that 2.7 billion workers (81\% of the global workforce) were affected by full or partial lock-in measures worldwide. Various scenarios predict an increase in unemployment ranging from 5.3 (optimistic scenario), 13 (medium scenario) and 24.7 million, not to mention underemployment, which is expected to "also increase on a large scale" (ILO, 2020d). For example, in France, between March and May 2020, the lockdown put 6.6 million employees on short-time working and 1 million self-employed people out of business due to the closure of non-essential shops, schools, day-care centers and administrative structures (OFCE, 2020a). In the United States, at the end of April 2020, the Analysis and Forecasting Department of the OFCE (2020b) estimated that $14.6 \%$ of total salaried employment had been destroyed.

The state intervention advocated by the Keynesians proved to be increased at the dawn of this health and social crisis. Containment measures and other restrictions, although heavy with consequences, have proved effective in containing the spread of the virus, but have slowed down the demand for (and supply of) labor, erasing in one quarter in the OECD ten years of employment growth since the 2008-2010 crisis (Anders et al., 2017). Recourse to short-time work, technical unemployment and other forms of work avoiding layoffs have been favored by the public authorities.

In the short term, the impact of the crisis has been "uneven across sectors and even across firms within the same sector". Activities requiring the effective presence of workers in the workplace have suffered the most, while the health sector, both in hospitals and in the pharmaceutical and medical equipment industries, has experienced "an exceptional increase in activity" (Superior Council of Employment/SCE, 2020). In developed countries, the temporary unemployment of workers has been accompanied by unemployment benefits, a system not used in poor countries. In developing countries, in order to mitigate the effects of the crisis on vulnerable populations, governments have resorted to social safety net programs through cash transfers intended for specific groups of people.

Recent studies (Superior Council of Employment/SCE, 2020; ILO, 2020a; ILO, 2020b) show that the pandemic has had a disproportionate impact on specific groups of people, such as minorities or aboriginals in Canada. Young people under the age of 30 have less seniority in entreprises and have suffered the most from layoffs. Women are "over-represented" in sectors where closure has been made compulsory and in the health sector ( $81 \%$ of health professionals in Belgium are women). 
The estimated 2 billion informal sector workers and entrepreneurs, most of whom have no social protection, were "forced to expose themselves and their families to COVID-19 in large numbers". A study of informal economy enterprises and workers in Senegal reveals job losses, partial or total loss of income, exacerbation of inequalities and resilience strategies of entrepreneurs (ILO, 2020c).

It should be noted that the sectors most affected by the crisis are also those in which the majority of informal economy unities operate. The impact of this crisis on the jobs of domestic workers is particularly alarming. Indeed, the ILO estimated in June 2020 that $72.3 \%$ of domestic workers were severely affected (loss of jobs and hours of work) by COVID-19 (ILO, 2020d).

The studies conducted in the subregion and in Togo on the impact of the pandemic on the private sector were mostly preliminary assessments of the impact of the pandemic on businesses. The studies for Togo have been discussed in various sections of this brief. With regard to the other crises previously mentioned, it appears that response measures such as border closures, curfews, quarantine and social distancing have always been favored in the event of a health crisis in order to limit the massive loss of human life. The direct consequences of all these health crises, such as COVID-19, are increased employee absenteeism due to infection or response measures, disruption of the global supply chain, and reduced business activity. Layoffs or mass closures in the sectors most affected by the crisis have always been the response. Historically, the public, service, trade, catering and industrial sectors have been the most likely to be affected.

Social dialogue has been a key tool to accompany the effects of the 2008-2010 crisis on the labour market. The study of the French Association of Economic Science (2012) showed that states where social dialogue was weak, a massive destruction of jobs had been observed, hence the need to also focus in our study on the impact of COVID-19 on labour relations in private entreprises and UPI.

\section{Methodology}

The documentary research was the key point of our methodology. It consisted of consulting scientific works (books, dissertations, articles, theses, official publications, archives, activity reports and official reports and documents of structures in charge of employment and labour issues, in particular the General Directorate of Employment (DGE), the General Directorate of Labour (DGT) and the National Employment Agency (ANPE). We also interviewed actors in the labour administration system, those responsible for producing general statistics like the National Institute of Statistics and Economic and Demographic Studies (INSEED) and specific employment and labour issues (the ANPE's Employment Observatory). The survey carried out by the DGT in October 2020 seems to us to be the best way to reach our goals and to allow us to validate or invalidate our hypotheses.

Nowadays, the labour administration and inspection system in Togo is composed of a central level (DGT and its central directorates) and a deconcentrated 
level (regional directorates of labour and social laws and the prefectural labour and social laws inspections). In 2018, Togo had four (4) central directorates, six (6) regional directorates of labour and social laws (DRTLS) and seventeen (17) operational labour inspectorates out of the thirty-two (32) created (DGT, 2018).

With the occurrence of the pandemic and strongly aware of the difficulties faced by actors in the world of work, the DGT through its zone inspections conducted a survey in the six (6) administrative regions of the country to assess the prevention and control mechanisms against COVID-19 in private entreprises and unities of the informal economy. This survey was carried out by their experienced labour inspectors, who are used to making visits to private entreprises and unities of the informal economy to assess the situation, carry out general inspections, and carry out targeted inspections and monitoring.

Indeed, the database was originally designed for the evaluation of workplace prevention and control measures. Our analysis consisted of focusing on the questionnaire items that dealt with the impact of the pandemic on activities, jobs and professional relations. The analysis of the database allowed us to review the variables and identify the coding used before the data was entered. It also allowed us to identify the relevant variables for our research. We have tried to clear the database in SPSS software, taking into account the variables of interest

Data cleaning consisted of correcting inconsistencies and errors in the database in order to obtain a reliable database. Various consistency and validity checks were performed manually and with the help of syntax programs in SPSS 21 software.

The statistical analysis of the data was done after this preliminary work. It consisted of first recoding some variables as needed and generating simple tables, cross-tabulations and graphs in the SPSS 21 software. Word and Excel were used to format the tables and generate some of the graphs. The responses to the open-ended questions (qualitative data) were manually analyzed in Excel to determine the most frequent responses. As with any scientific approach, our research was faced with difficulties and is subject to limitations.

The difficulties encountered during our research are the following:

- The pandemic context in which the country is immersed (closure of certain cities, authorizations to be taken for a survey...) as well as the temporal and financial constraints did not allow us to conduct a survey as we would have wished in order to collect data specific to our study;

- Since the phenomenon (COVID-19) is recent, few studies (or none for certain structures) or data/estimates have been produced by the structures responsible for promoting employment and producing statistics on employment. However, some structures have been reluctant to communicate the results of surveys that have not yet been validated.

The main limitation is the extrapolation of data to all private enterprises and unities of the informal economy in Togo, given the number of unities surveyed, i.e., two hundred and eighty-one (281). 


\section{Pandemic of COVID-19, Private Entreprises and Informal Economy Unities in Togo: Analysis and Discussion of Results}

The analysis of the results of the respondents requires first of all an understanding of the sample surveyed (1). Since the topic is about the impact of the pandemic on the unities, it seems appropriate to also identify the level of knowledge of the unities about the central issue (COVID-19) and the attitude adopted towards it (2). Next, we will look at the impact of the pandemic on private enterprises and informal production unities (IPU).

Given the weight of the informal economy in Togo (as a reminder, the informal sector contributes between 20 and $30 \%$ of the national GDP (IMF, 2017)) and its importance in terms of jobs provided to the population $(87.9 \%$ of non-agricultural jobs are provided by the informal sector (INSEED, 2019)), $48.40 \%$ of the unities surveyed are informal production unities (IPU) as opposed to $51.60 \%$ of formal private enterprises (free trade zone and customs zone). These IPUs take various forms, namely those that are individual unities (86.76\%) versus those that are family unities, associations, cooperatives or groupings (13.24\%).

The spatial distribution reveals that of the 281 unities surveyed, 90 unities are in the Lomé-Commune region, making it the region with the largest number of unities surveyed. This region, along with the Maritime region, is also the region in which the number of informal economy unities surveyed exceeds the number of private enterprises (database/2020).

The private enterprises (customs zone) and PIUs surveyed as part of the study (DGT) operate in various sectors of the economy and their activities are varied, regardless of their status, whereas those in the free zone seem to operate exclusively in the industrial sector (DGT Database, 2020 and Figure 2).

In the light of the distribution by economic sector, it appears that the majority of unities carry out activities belonging to the tertiary sector (88.58\%), with trade (29.2\%) being the most preponderant (Figure 2).

Nowadays, unities are increasingly resorting to subcontracting in order to remain competitive and develop their markets in an "increasingly tense economic and competitive context according to Entrepreneurial Dynamics (2020) in Togo. The Togolese unities are no exception, with $14.5 \%$ of unities claiming to subcontract (Table 3) at different levels. However, all those that "always" subcontract are private entreprises in the customs area.

The unities surveyed together employed 8778 workers on the date of the survey. Private enterprises in the free zone (2238) and the customs zone (5457) together employ $87.66 \%$ of these workers according to DGT Database, 2020. The statistics in the Table 4 showed that the majority of these unities have a workforce of between 0 and 10 people (55.87\%) and between 11 and 24 people (22.06\%). These two intervals account for almost all the staff of the PIUs, revealing that the PIUs employ few workers per unit. Private entreprises in the free 
Table 3. Distribution of subcontracted and non-subcontracted unities by status.

\begin{tabular}{cccccc}
\hline \multirow{2}{*}{ Never } & Free Zone & Customs zone & $\begin{array}{c}\text { Informal } \\
\text { production unities }\end{array}$ \\
& Observations & 6 & 115 & 114 & 235 \\
& Percentage & $100.00 \%$ & $83.33 \%$ & $87.02 \%$ & $85.45 \%$ \\
\hline \multirow{2}{*}{ Rarely } & Observations & 0 & 9 & 11 & 20 \\
& Percentage & $0.00 \%$ & $6.52 \%$ & $8.40 \%$ & $7.27 \%$ \\
\hline \multirow{2}{*}{ Frequently } & Observations & 0 & 9 & 6 & 15 \\
& Percentage & $0.00 \%$ & $6.52 \%$ & $4.58 \%$ & $5.45 \%$ \\
\hline \multirow{2}{*}{ always } & Observations & 0 & 5 & 0 & 5 \\
& Percentage & $0.00 \%$ & $3.62 \%$ & $0.00 \%$ & $1.82 \%$ \\
\hline \multirow{2}{*}{ Total } & Observations & 6 & 138 & 131 & 275 \\
& Percentage & $100.00 \%$ & $100.00 \%$ & $100.00 \%$ & $100.00 \%$ \\
\hline
\end{tabular}

Source: Author, from DGT Database, 2020.

Table 4. Distribution of the current workforce in the surveyed unities by status.

\begin{tabular}{|c|c|c|c|c|c|c|c|}
\hline & & \multicolumn{6}{|c|}{ Current number of unities per class } \\
\hline & & {$[0-10]$} & {$[11-24]$} & {$[25-50]$} & {$[51-100]$} & [101 - 200] & $\begin{array}{c}\text { Over } \\
\text { than } 201\end{array}$ \\
\hline \multirow{2}{*}{ Free Zone } & workforce & 0 & 0 & 0 & 0 & 1 & 5 \\
\hline & $\%$ line & $0.00 \%$ & $0.00 \%$ & $0.00 \%$ & $0.00 \%$ & $16.67 \%$ & $83.33 \%$ \\
\hline \multirow{2}{*}{$\begin{array}{l}\text { Customs } \\
\text { zone }\end{array}$} & workforce & 53 & 36 & 27 & 13 & 3 & 7 \\
\hline & $\%$ line & $38.13 \%$ & $25.90 \%$ & $19.42 \%$ & $9.35 \%$ & $2.16 \%$ & $5.04 \%$ \\
\hline \multirow{2}{*}{$\begin{array}{l}\text { Unity of } \\
\text { informal } \\
\text { economy }\end{array}$} & workforce & 104 & 26 & 5 & 1 & 0 & 0 \\
\hline & $\%$ line & $76.47 \%$ & $19.12 \%$ & $3.68 \%$ & $0.74 \%$ & $0.00 \%$ & $0.00 \%$ \\
\hline \multirow{2}{*}{ Total } & workforce & 157 & 62 & 32 & 14 & 4 & 12 \\
\hline & $\%$ line & $55.87 \%$ & $22.06 \%$ & $11.39 \%$ & $4.98 \%$ & $1.42 \%$ & $4.27 \%$ \\
\hline
\end{tabular}

Source: Author, from DGT Database, 2020.

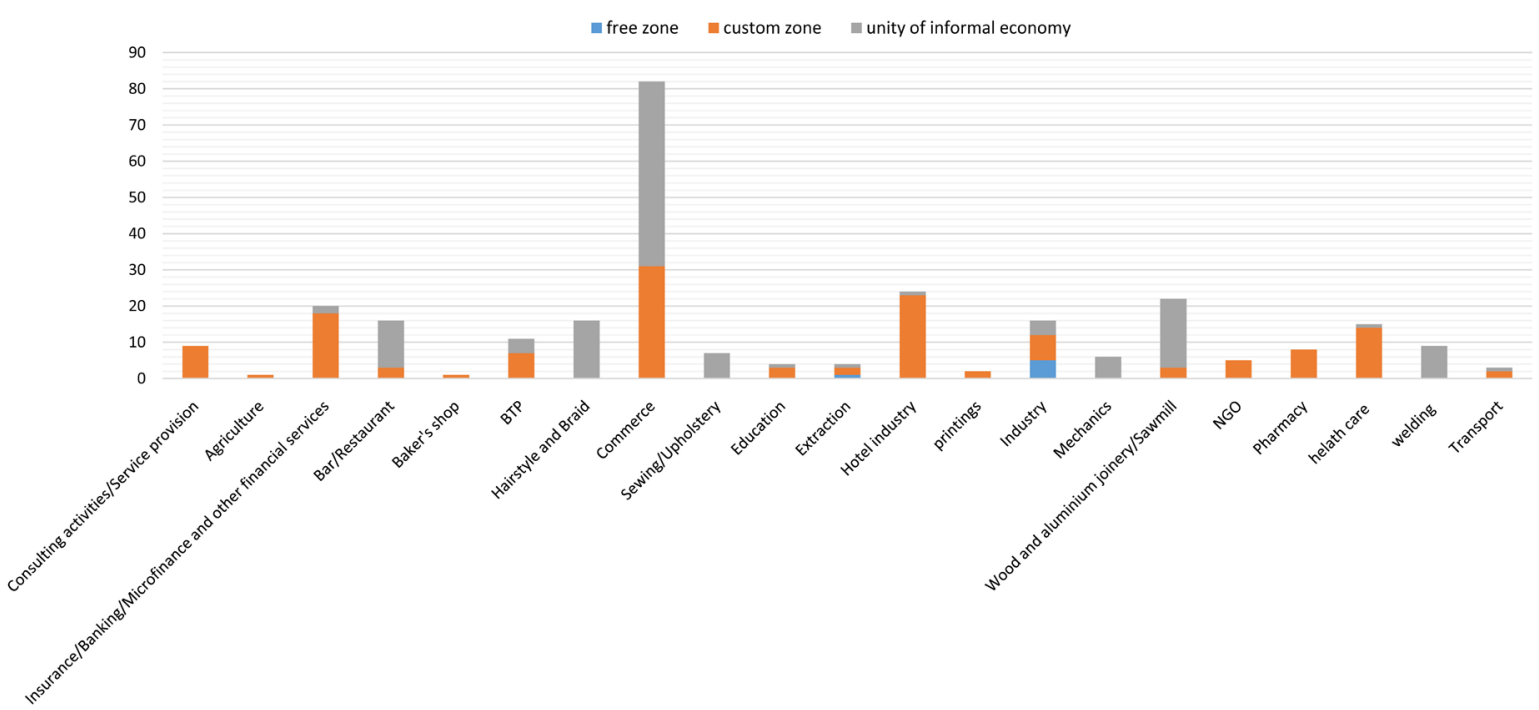

Figure 2. Distribution of the activities of the unities according to their status. Source: Author, constructed from DGT Database, 2020 . 
zone employ more than 100 people per unit, while the statistics for those in the customs zone are diverse.

By region, it appears that the unities in the Lomé-Commune region have the largest number of workers, with 3447 workers (DGT Database, 2020). However, the number of workers at the time of the survey does not reflect the situation before the health crisis.

The characteristics of the sample highlight the need to take into account the major macroeconomic trends in Togo, which is why the PIUs were taken into account in order to determine the impact of this pandemic on this sector, which tends to be overshadowed by the "regal" control of the State. The representativeness of the activities of the tertiary sector is also telling, knowing the contribution of this sector to the national GDP in recent years.

The hemorrhagic fever with the new Coronavirus has been raging throughout the world since December 31, 2020, broke out in the city of Wuhan in China. The international organizations (WHO, ILO...) and the governments of all countries are raising awareness among the populations and in particular the actors of the working world who are the most exposed to the risks of contamination in their workplace. Tools have also been developed to enable employers to adapt workplaces to current requirements (ILO, 2020e) and barrier measures have been enacted to reduce the risks of contamination (WHO, Togolese government, ILO...). To this end, $46.59 \%$ of the unities have rearranged their workplaces to respect the physical distance ( 1 meter). By status, it appears that only $31.34 \%$ of PIUs have rearranged their workplaces to respect the distance against $66.67 \%$ of unities in the free zone and $60.43 \%$ of unities in the customs zone (Table 5).

In the context of a health crisis where the provision of anti-COVID-19 equipment by the unities and the systematic use of this equipment are advocated by the public authorities, the analysis reveals a strong provision of masks (59.07\%) than hydroalcoholic gels (35.59\%) with the informal production unities being more inclined to provide their employees with masks (65.44\%) and other equipment (DGT Database, 2020).

However, the use of masks in the workplace is mixed $(51.44 \%$ of the unities opted for the systematic wearing of masks by users/visitors/customers in their

Table 5. Workplace adjustment by status.

\begin{tabular}{|c|c|c|c|c|c|}
\hline & & Free zone & Customs & $\begin{array}{c}\text { Unity of informal } \\
\text { economy }\end{array}$ & Total \\
\hline \multirow[b]{2}{*}{ Yes } & Observations & 4 & 84 & 42 & 130 \\
\hline & $\%$ column & $66.67 \%$ & $60.43 \%$ & $31.34 \%$ & $46.59 \%$ \\
\hline \multirow[b]{2}{*}{ NO } & Observations & 2 & 25 & 75 & 102 \\
\hline & $\%$ column & $33.33 \%$ & $17.99 \%$ & $55.97 \%$ & $36.56 \%$ \\
\hline \multirow{2}{*}{ Not necessary } & Observations & 0 & 30 & 17 & 47 \\
\hline & $\%$ column & $0.00 \%$ & $21.58 \%$ & $12.69 \%$ & $16.85 \%$ \\
\hline
\end{tabular}

Source: Author, from DGT Database, 2020. 
premises). In fact, the systematic wearing of masks is more popular in private entreprises in the free zone (83.33\%) and the customs zone (68.61\%) than in the PIUs (32.59\%) (Figure 3).

The hand-washing system within the unities and the taking of temperatures on entry are two essential elements in reducing the risk of contamination and in the rapid detection of one of the probable symptoms of the disease (WHO). The survey reveals that almost all private entreprises (100\% for unities in the free zone and $93.53 \%$ of unities in the customs zone) have a hand-washing device, whereas $34.33 \%$ of PIUs do not. The taking of temperatures on entry is neglected in the PIUs (2.21\%) and private entreprises in the customs zone (25.18\%), whereas all those in the free zone (100\%) do so. Unfortunately, in almost half of the unities (45.20\%) where symptoms of COVID-19 are detected, no action is taken (DGT Database, 2020).

The section focused on the knowledge of the disease by the actors in the surveyed unities and their consideration of barrier measures in different proportions. Private entreprises were more inclined to take the necessary measures to respect the barrier measures and individual and interpersonal protection measures than the informal economy unities. Despite the waves of awareness-raising that have already taken place throughout the country, they should be renewed in the workplace.

Beyond the effects of this crisis on the health and lives of millions of people, it seems to impact the functioning of the unities through the measures taken by the governments (ILO, 2020b).

The statistics in Table 6 showed that almost all of the unities surveyed (96.80\%) claim to have been affected by the crisis (impact on the operation of their unities). The informal economy unities (97.79\%) were more affected than the others $(83.33 \%$ of unities in the free zone and $96.40 \%$ of unities in the customs zone). This led to $93.2 \%$ of unities experiencing a "decline" in their activities, compared with $1.1 \%$, or 3 unities that experienced an "increase" in their activities (DGT Database, 2020). The latter is active in the pharmaceutical, bar/restaurant and mining industries.

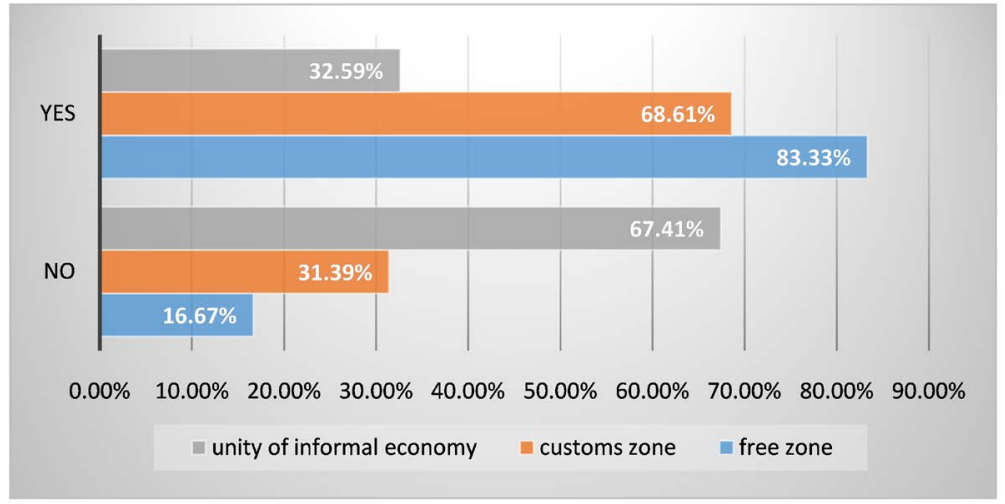

Figure 3. Systematic wearing of masks in the unities. Source: Author, constructed from DGT Database, 2020. 
Table 6. Impact of the health crisis on private enterprises and informal economy unities.

\begin{tabular}{ccccc}
\hline & & yes & NO & Total \\
\hline \multirow{2}{*}{ Free zone } & Observations & 5 & 1 & 6 \\
& \% column & $83.33 \%$ & $16.67 \%$ & $100.00 \%$ \\
\hline Customs zone & workforce & 134 & 5 & 139 \\
& \% column & $96.40 \%$ & $3.60 \%$ & $100.00 \%$ \\
\hline Unity of informal economy & workforce & 133 & 3 & 136 \\
& \% column & $97.79 \%$ & $2.21 \%$ & $100.00 \%$ \\
\hline Total & workforce & 272 & 9 & 281 \\
& \% column & $96.80 \%$ & $3.20 \%$ & $100.00 \%$ \\
\hline
\end{tabular}

Source: Author, from DGT Database, 2020.

However, the decline in unit activities is not necessarily due to confirmed or suspected COVID-19 cases in the unities (DGT Database, 2020). In fact, only 4 unities had confirmed cases of COVID-19 (all are private entreprises in the customs area). Of the confirmed cases, none came from a unit in the Lomé-commune region, the region with the largest number of confirmed COVID-19 cases in Togo. The suspected cases ( 85 workers) were identified in 5 unities. The majority of confirmed and suspected cases were detected in unities operating in the health sector (8 infected persons and 83 suspected cases).

Faced with this situation, $72.95 \%$ of the unities decided to take measures to reorganize their unities in order to sustain their activities. According to DGT Database, 2020 and by status, PIUs have the lowest proportion of unities (65.44\%) that have resorted to reorganization. Private entreprises and PIUs frequently resorted to the following reorganization measures: rotation $(28.09 \%)$, continuous working day (15.73\%), reduction of working hours $(14.04 \%)$, rearrangement of working hours (9.55\%) and partial closure (8.99\%). On the whole, the use of extreme measures was avoided, namely redundancy (1.69\%) and short-time working $(2.81 \%)$, while some unities used a combination of several measures. DGT Database, 2020 confirmed that, in terms of status, it appears that private entreprises had more recourse to measures requiring the mastery of new information and communication technologies (remote work, digitalization, virtual meetings) than unities in the informal economy.

The entreprises have obviously pointed out the difficulties related to COVID-19 that they encounter. It is clear that in the majority of unities the difficulties related to COVID-19 are more economic than health-related. Indeed, only $2.16 \%$ of the unities mentioned health-related difficulties as their main difficulty, as opposed to $80.17 \%$ of the unities that are facing economic difficulties as a result of the drop in their level of activity. The PIUs (89.66\%) were more concerned by these economic difficulties than the private entreprises (70.69\%) (Table 7).

Other difficulties mentioned include: the drop in the number of clients, supply difficulties related to imports, cash flow difficulties for loan repayment or 
Table 7. Main difficulties related to COVID-19 encountered by the unities by status.

\begin{tabular}{ccccc}
\hline & & $\begin{array}{c}\text { Private entreprises } \\
\text { (free zone and } \\
\text { customs zone) }\end{array}$ & $\begin{array}{c}\text { Unity of } \\
\text { informal } \\
\text { economy }\end{array}$ & Total \\
\hline $\begin{array}{c}\text { Insufficient cash flow to } \\
\text { maintain staff and } \\
\text { operations/Raw materials } \\
\text { not available/Poor sales }\end{array}$ & Percentage column & $70.69 \%$ & $89.66 \%$ & $80.17 \%$ \\
\hline $\begin{array}{c}\text { Workers are absent due to } \\
\text { COVID-19/Workers are } \\
\text { absent due to government } \\
\text { instructions in the fight } \\
\text { against COVID-19 }\end{array}$ & percentage column & $3.45 \%$ & $0.86 \%$ & $2.16 \%$ \\
\hline Other difficulties & workforce & 30 & 11 & 41 \\
\hline Total & Percentage column & $25.86 \%$ & $9.48 \%$ & $17.67 \%$ \\
\hline
\end{tabular}

Source: Author, from DGT Database, 2020.

settlement of outstanding payments, or to support additional expenses induced by the pandemic, such as the payment of personal protective equipment (protective mask, gang, etc.).

In the previous sections of our analysis, the impact of the crisis on the functioning of the unities was mentioned at various levels, as well as the difficulties related to this crisis that the unities are facing, such as insufficient cash flow to retain staff. What is the real impact on the number of workers in the unities surveyed?

The database (Table 8) revealed that the 281 unities employed 9883 workers before the health crisis, compared to 8778 currently. This represents an overall loss of 1105 jobs, or a contraction of $11.18 \%$. By status, slightly more than half (51\%) of the jobs lost were in private enterprises in the customs area, while $14 \%$ of these jobs were lost in informal economy unities (Figure 4).

The spatial distribution reveals, however, that the Central and Savannah regions concentrate the greatest number of job losses, with 394 and 335 jobs lost respectively. However, these figures are not indicative of the situation in all unities.

In fact, $59.43 \%$ (167) of the unities have maintained their pre-crisis workforce despite the slowdown in their activities. Source of reference not found). Among the unities (87) that have been forced to shed some of their workers, $50.57 \%$ are private entreprises in the customs area. However, $9.61 \%$, or 27 of the unities surveyed, have seen an increase in their workforce. Of these, $62.96 \%$ were private entreprises in the customs zone, compared with $0 \%$ in the free zone (Table 9).

According to DGT Database, 2020, the statistics on changes in the workforce by gender showed that men and women were affected differently by the loss of jobs in the unities. With the 1105 jobs lost, 705 were for male workers, or $10.47 \%$ of the jobs lost for men. On the side of female workers, $12.70 \%$ of their workforce 


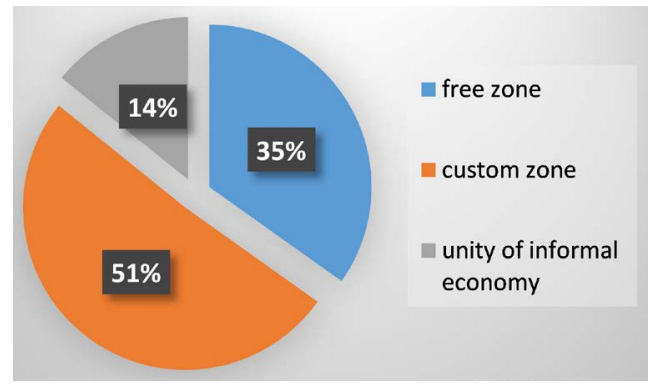

Figure 4. Distribution of job losses by status. Source: Author, based on DGT Database, 2020.

Table 8. Total number of unities.

\begin{tabular}{cc} 
Workforce before the crisis & 9883 \\
Current headcount (headcount at the time of the survey) & 8778 \\
Difference & $-1105(-11.18 \%)$ \\
\hline
\end{tabular}

Source: Author, from DGT Database, 2020.

Table 9. Changes in the number of employees in unities by status.

\begin{tabular}{|c|c|c|c|c|c|}
\hline & & Decrease & Stable & increase & Total \\
\hline & Observations & 3 & 3 & 0 & 6 \\
\hline \multirow[t]{3}{*}{ Free zone } & $\%$ line & $50.00 \%$ & $50.00 \%$ & $0.00 \%$ & $100.00 \%$ \\
\hline & $\%$ column & $3.45 \%$ & $1.80 \%$ & $0.00 \%$ & $2.14 \%$ \\
\hline & Observations & 44 & 78 & 17 & 139 \\
\hline \multirow[t]{3}{*}{ Customs zone } & $\%$ line & $31.65 \%$ & $56.12 \%$ & $12.23 \%$ & $100.00 \%$ \\
\hline & $\%$ columne & $50.57 \%$ & $46.71 \%$ & $62.96 \%$ & $49.47 \%$ \\
\hline & Observations & 40 & 86 & 10 & 136 \\
\hline \multirow[t]{3}{*}{$\begin{array}{c}\text { Unity of } \\
\text { informal economy }\end{array}$} & $\%$ line & $29.41 \%$ & $63.24 \%$ & $7.35 \%$ & $100.00 \%$ \\
\hline & $\%$ column & $45.98 \%$ & $51.50 \%$ & $37.04 \%$ & $48.40 \%$ \\
\hline & Observations & 87 & 167 & 27 & 281 \\
\hline \multirow[t]{2}{*}{ Total } & $\%$ line & $30.96 \%$ & $59.43 \%$ & $9.61 \%$ & $100.00 \%$ \\
\hline & $\%$ column & $100.0 \%$ & $100.0 \%$ & $100.0 \%$ & $100.0 \%$ \\
\hline
\end{tabular}

Source: Author, based on DGT Database, 2020.

has been reduced. According to the status, women were more affected by the loss of jobs in the free zone $(18.76 \%)$ while men were more affected in the informal economy (12.85\%).

In this context of health crisis, where entreprises were forced to separate their employees by opting for technical unemployment or outright dismissals, labour relations are the focus of attention. In the unities surveyed, $7.12 \%$ had to resort to short-time working and $5.34 \%$ had to resort to dismissal. Both situations were observed in private entreprises in the customs area and in the PIUs. The PIUs had more recourse to layoffs ( $8.09 \%$ of PIUs), while private entreprises in the customs area had more recourse to short-time working (10.79\% of private en- 
treprises in the customs area), reflecting the willingness of the latter to preserve jobs despite their economic situation (Table 10).

The Togolese labour code, which provides for technical unemployment, the suspension of all or part of a company's activities under specific conditions (serious economic difficulties or an event of force majeure), stipulates that the matter be referred without delay to the labour inspectorate, which is responsible for "ruling on the validity of the measure" (Togolese Republic, 2006). In this regard, $33.33 \%$ of the unities in the customs zone that implemented short-time working referred the matter to the zone labour inspectorate, while none of the PIUs did so.

A total of 289 workers were affected by the above-mentioned short-time working situations, compared to 49 workers who were laid off, 39 of whom were in the PIUs. The majority of workers affected by short-time working are employed by private entreprises in the customs area. By gender, the analysis reveals a higher proportion of men who were laid off $(76.92 \%)$ and men who were laid off on short time (55.17\%) according to DGT Database, 2020.

Among these laid-off workers, there are no staff representatives. The people in apprenticeship positions in the unities were not spared the generalized situation in the unities. In fact, there were 11 cases of breach of apprenticeship contracts and 32 cases of abandonment. The men were more affected by the situation of rupture and the women more by that of abandonment (Table 11).

Table 10. Unities' use of short-time work, referral to labour inspection and dismissal by status.

\begin{tabular}{|c|c|c|c|c|c|c|}
\hline & & \multicolumn{2}{|c|}{ Technical unemployment } & \multirow{2}{*}{$\begin{array}{l}\text { Referral to } \\
\text { the labour } \\
\text { inspectorate }\end{array}$} & \multicolumn{2}{|c|}{ Dismissal } \\
\hline & & $\begin{array}{l}\text { Unities that } \\
\text { used Total }\end{array}$ & & & $\begin{array}{l}\text { Unities that } \\
\text { used Total }\end{array}$ & \\
\hline \multirow{2}{*}{$\begin{array}{l}\text { Free } \\
\text { zone }\end{array}$} & Observations & 0 & 6 & 0 & 0 & 6 \\
\hline & $\%$ line & $0.00 \%$ & $100.00 \%$ & $0.00 \%$ & $0.00 \%$ & $100.00 \%$ \\
\hline \multirow{2}{*}{$\begin{array}{l}\text { Customs } \\
\text { zone }\end{array}$} & Observations & 15 & 139 & 5 & 4 & 139 \\
\hline & $\%$ line & $10.79 \%$ & $100.00 \%$ & $33.33 \%$ & $2.88 \%$ & $100.00 \%$ \\
\hline \multirow{2}{*}{$\begin{array}{l}\text { Unity of } \\
\text { informal } \\
\text { economy }\end{array}$} & Observations & 5 & 136 & 0 & 11 & 136 \\
\hline & $\%$ line & $3.68 \%$ & $100.00 \%$ & $0.00 \%$ & $8.09 \%$ & $100.00 \%$ \\
\hline \multirow{2}{*}{ Total } & Observations & 20 & 281 & 5 & 15 & 281 \\
\hline & $\%$ line & $7.12 \%$ & $100.00 \%$ & $25.00 \%$ & $5.34 \%$ & $100.00 \%$ \\
\hline
\end{tabular}

Source: Author, from DGT Database, 2020.

Table 11. Situation of staff representatives and apprentices in the unities.

\begin{tabular}{cccccccccc}
\hline & \multicolumn{2}{c}{$\begin{array}{c}\text { Staff representatives } \\
\text { Licensees }\end{array}$} & \multicolumn{2}{c}{$\begin{array}{c}\text { Broken apprenticeship } \\
\text { contracts }\end{array}$} & \multicolumn{3}{c}{$\begin{array}{c}\text { Abandonment of } \\
\text { apprenticeship contracts }\end{array}$} \\
\cline { 2 - 10 } & Men & Women & Total & Men & Women & Total & Men & Womeb & Total \\
\hline workforce & 0 & 0 & 0 & 9 & 2 & 11 & 9 & 23 & 32 \\
$\%$ line & - & - & - & $81.82 \%$ & $18.18 \%$ & $100.00 \%$ & $28.13 \%$ & $71.88 \%$ & $100.00 \%$ \\
\hline
\end{tabular}

Source: Author, from DGT Database, 2020. 
Unities that have opted for technical unemployment have logically had to reduce their payroll. Since labour legislation is not specific about salary compensation in the event of technical unemployment (Article 57 of the Togolese Labour Code), it appears that $42.86 \%$ of the unities in the customs zone opted for a reduction in the wage bill of less than $25 \%$, while half of the PIUs had to resort to a reduction of between 50 and $75 \%$ of the pre-crisis wage bill. No UPI opted for a reduction of more than $75 \%$ (DGT Database, 2020).

Conflicts arose from the different management methods used by employers during COVID-19, and some unities "favored negotiation" as a guarantee of good faith and respect for the interests of workers, as recommended by the Togolese legislator, in order to maintain good labour relations. With the unities surveyed, $3.91 \%$ had experienced collective conflicts during this period. The main reason for these collective conflicts was the drop in workers' pay as a result of the difficulties linked to COVID-19, which was very often combined with other reasons (organization of working hours, reduction in the number of staff and barrier measures). The $50 \%$ of the unities involved in collective disputes also mentioned unemployment pay, late payment of wages and breach of contract as reasons.

Some unities (18.51\%) have negotiated with workers or their representatives (Table 12) to avoid collective or individual conflicts. A higher proportion of unities $(66.67 \%)$ in the free zone have done this. The reasons for the various negotiations were diverse. However, the main reasons for negotiation were a reduction in remuneration and/or its association with reasons such as the organisation of working hours, a reduction in the number of staff and barrier measures (DGT Database, 2020).

In order to involve workers in the chain of control of COVID in the workplace and thereby enable their active participation, $22.06 \%$ of the unities report having involved workers or their representatives in this process. The unities in the customs zone (83.33\%) are those that have involved the most workers or their representatives in the fight against COVID-19 in the workplace, compared to a low involvement of workers in the PIUs (8.08\%) (Table 13).

Table 12. Collective conflicts during the COVID-19 period and negotiations with workers or their representatives.

\begin{tabular}{|c|c|c|c|c|}
\hline & & $\begin{array}{l}\text { Unities with collective } \\
\text { conflicts during COVID-19 }\end{array}$ & $\begin{array}{l}\text { Unities that have conducted } \\
\text { negotiations with workers/representatives }\end{array}$ & Total \\
\hline \multirow{2}{*}{ Free zone } & Observations & 1 & 4 & 6 \\
\hline & $\%$ line & $16.67 \%$ & $66.67 \%$ & $100.00 \%$ \\
\hline \multirow{2}{*}{$\begin{array}{l}\text { Customs } \\
\text { zone }\end{array}$} & Observations & 7 & 33 & 139 \\
\hline & $\%$ line & $5.04 \%$ & $23.74 \%$ & $100.00 \%$ \\
\hline \multirow{2}{*}{$\begin{array}{l}\text { Unity of } \\
\text { informally } \\
\text { economy }\end{array}$} & Observations & 3 & 15 & 136 \\
\hline & $\%$ line & $2.21 \%$ & $11.03 \%$ & $100.00 \%$ \\
\hline \multirow{2}{*}{ Total } & Observations & 11 & 52 & 281 \\
\hline & $\%$ line & $3.91 \%$ & $18.51 \%$ & $100.00 \%$ \\
\hline
\end{tabular}

Source: Author, from DGT Database, 2020. 
Table 13. Involvement of workers or their representatives in the fight against COVID-19 in the workplace.

\begin{tabular}{cccc}
\hline & & $\begin{array}{c}\text { Unities involving workers or } \\
\text { their representatives in the } \\
\text { management of COVID-19 }\end{array}$ & Total \\
\hline Free zone & $\begin{array}{c}\text { Observations } \\
\% \text { line }\end{array}$ & 5 & 6 \\
\hline Customs & Observations & $83.33 \%$ & $100.00 \%$ \\
\hline Unity of informal & Observations & 46 & 139 \\
economy & $\%$ line & $33.09 \%$ & $100.00 \%$ \\
\hline Total & Observations & 11 & 136 \\
& $\%$ line & $8.09 \%$ & $100.00 \%$ \\
\hline
\end{tabular}

Source: Author, from DGT Database, 2020.

It should be noted that $40.32 \%$ of the unities that involved the workers did so for the entire chain: communication on protective measures, choice and implementation of measures, and follow-up of anti-COVID-19 measures. Some unities, however, involved the workers/representatives in only one or two of these aspects, reflecting a break in the chain of control of the spread of COVID-19 in the workplace (DGT Database, 2020).

\section{Conclusion}

Togo is affected by COVID-19 like all countries in the world. However, the health situation in Togo is not as alarming as in other countries, despite the fact that the health system is similar to that of poor countries. However, in an era of globalization where every country depends on the rest of the world, the effects of the pandemic on the Togolese economy have been felt very quickly. Our documentary research provided us with a database resulting from a survey conducted to evaluate the prevention and control of COVID-19. Our literature review provided us with information on how the labour market has historically responded to major economic and health crises.

The statistical analysis highlights the awareness of employers and workers of the phenomenon that is shaking the whole world and their appropriation of barrier measures. It reveals the decline in activities in the majority of the unities surveyed (93.1\%), especially in informal production unities (97.1\%), despite the use of various forms of reorganization advocated (rotation, continuous working day, reduction and arrangement of working hours, remote work, etc.). The drop in production (due to the unavailability of raw materials) and sales (due to poor sales) has led to a cash shortage in these unities, making it impossible to retain all the staff. The costs incurred by the acquisition of alcoholic gels, masks, hand washing devices, etc. have not improved the situation.

Some unities, especially those in the customs and free zone, have been forced 
to reduce their workforce by $11.18 \%$, representing a loss of 1105 jobs, while others have resorted to technical unemployment or partial closure of their activities. The Central and Savannah regions have the most workers who have lost their jobs as a result of the difficulties associated with COVID-19. The situation of apprentices has also changed. Indeed, employers have been forced to break apprenticeship contracts and to watch helplessly as more women have dropped out.

Industrial relations, although marked to a small extent by the involvement of workers or their representatives in the fight against COVID-19 in the workplace, have been marked by collective conflicts generated by the crisis and the use of negotiations to resolve various situations, mainly the reduction in remuneration. Labour relations, despite being marred by collective and individual conflicts, cannot be considered "degraded". Indeed, the involvement of workers or their representatives may have mitigated this tense work environment, and the use of the labour inspectorate by some private entreprises shows their desire to maintain good labour relations.

Following the results obtained, it is important to draw lessons in order to maximize good practices and make a contribution to a more adequate management of the COVID-19 in the workplace and to minimize the impact on private enterprises and informal economy unities.

In spite of the appropriation of the barrier measures, it is important to multiply the sensitization of employers and workers in the entreprises in order to avoid the creation of contamination centers in the workplaces. For the unities, the use of new information technologies (for telecommuting, e-commerce, virtual meetings) should reduce the risks of contamination in the workplace.

Planning for economic recovery at the macro and micro levels would be the best way to respond to this crisis. The State should study solutions for the recovery of the private sector and PIUs by effectively supporting them, allowing them access to financing, improving the business climate and strengthening the social dialogue mechanisms already in place at the national and unit levels. The strengthening of social dialogue mechanisms should make it possible to preserve stable labour relations that are a guarantee of results for workers.

Our study, by focusing on the impact of the pandemic on private entreprises and informal production unities, adds to the existing literature on the impact and consequences of the pandemic on the world of work. It also sheds light on what is happening to labour relations within these unities that have been forced to resort to new forms of work or to separate themselves from all or part of their workers. Our analysis is limited, however, by the availability of data on this topical issue that marked the year 2020. Data collection on a larger proportion of private firms and informal economy unities across the country would have allowed us to extrapolate our results to the whole of Togo. Further research could look at the impact of the pandemic on workers, who were either laid off or made redundant at some point or had their wages reduced, with a consequent impact on household income. 


\section{Conflicts of Interest}

The authors declare no conflicts of interest regarding the publication of this paper.

\section{References}

AfDB (2020). African Economic Outlook 2020: Training the African Workforce of Tomorrow.

Anders, B., Sven-Olov, D., \& Niklas, R. (2017). Employment Protection Legislation and Firm Growth: Evidence from a Natural Experiment. Industrial and Corporate Change, 26, 169-185. https://doi.org/10.1093/icc/dtw017

ANPE/Togo (2019). Togo Decent Work Country Profile.

Article 142 of the Togolese Labour Code (2006). Togo-Labour Code-ILO. http://www.droit-afrique.com/

Article 57 of the Togolese Labour Code (2006). Togo-Labour Code-ILO. http://www.droit-afrique.com/

Bentone, A., Cazorla, A., \& Hemdane, E. (2019). Dictionary of Economics (6e éd.). Malakoff: Dunod.

Brainerd, E., \& Siegler, M. (2003). The Economic Effects of the 1918 Influenza Epidemic. United States: Center for Economic Policy Research.

CCIT (2020). Effects of the COVID-19 Health Crisis on the Activities of Togolese Private Sector Enterprises.

CNP (2020). Analysis of the Impact of the COVID-19 Pandemic on Businesses in Togo.

DGT (2018). Labour Inspection System Activity Report 2018.

DGT (2020). General Directorate of Labour-Togo, 2020.

DGT Database (2020). General Directorate of Labour-Togo, Database, 2020.

DORSAN (2020). The Economic Impact of COVID-19 in the World: Dorsan Living Filtration. https://www.dorsanfiltration.com/fr/el-impacto-economico-del-covid-19

ECA (2015). Socio-Economic Impacts of Ebola on Africa. Addis Ababa.

ECOWAS, CILSS, PAM, FEWS, \& NET/USAID (2006). Socio-Economic Impacts of Avian Influenza in West Africa: "A Case Study of Nigeria”.

Entrepreneurial Dynamics (2020). Dynamic-Mag. https://www.dynamique-mag.com/article/les-regles-de-la-sous-traitance.4866

ERI-ESI (2017). Regional Final Report: Integrated Regional Survey on Employment and the Informal Sector, WAEMU.

French Association of Economic Science (2012). The Urgency of Social Dialogue-Report of the Interview of the French Association of Economic Science. Journal of Political Economy, 122, 321-334.

https://www.cairn.info/revue-d-economie-politique-2012-3-page-321.htm https://doi.org/10.3917/redp.223.0321

ILO (2019). Global Employment and Social Issues: Trends 2019. Geneva.

ILO (2020a). Policy Brief: Impact of Containment Measures on the Informal Economy. Geneva.

ILO (2020b). COVID-19 and the World of Work: Updated Estimates and Analyses (2nd ed.). Geneva.

ILO (2020c). Summary Note-Study of the Impact of COVID-19 on Informal Economy 
Enterprises and Workers in Senegal. Geneva.

ILO (2020d). COVID-19 Crisis and Loss of Jobs and Hours among Domestic Workers. Geneva.

ILO (2020e). Returning to Work Safely: A Guide for Employers on the Prevention of COVID-19. Geneva.

IMF (2017). Regional Economic Outlook for Sub-Saharan Africa: Getting Growth Back on Track (pp. 53-72). Washington DC: International Monetary Fund.

IMF (2020a). World Economic Outlook Update. Washington DC: International Monetary Fund.

IMF (2020b). World Economic Outlook Update. Washington DC.

INSEED (2016). Unified Core Indicators of Well-Being Questionnaire 2015. Lomé.

INSEED (2019). Integrated Regional Survey on Employment and the Informal Sector 2017. ERI-ESI.

INSEED, UNDP (2017). Togo: Poverty Mapping.

John Hopkins University (2020). COVID-19 Map-Johns Hopkins, Coronavirus Resource Center.

Johnson, N., \& Mueller, J. (2002). Updating the Accounts: Global Mortality of the 19181920 "Spanish" Influenza Pandemic. Bulletin of the History of Medicine, 76, 105-115. https://doi.org/10.1353/bhm.2002.0022

Morin, H. (2012). The World. Is the Mortality Linked to the H5N1 Virus Overestimated? theworld.fr.

MPDC (2018). National Development Programm 2018-2022. Lomé.

MTESS (2014). Diagnostic Study and Elements of Priority Actions in Favor of the Access of Disabled People to the Labour Market in Togo.

OFCE (2020a). Assessment as of May 6, 2020 of the Economic Impact of the COVID-19 Pandemic and Containment Measures on the French Labour Market. OFCE Policy Brief 67.

OFCE (2020b). Assessment of the COVID-19 Pandemic on the World Economy. Revue de l'OFCE, 116, 59-110. https://www.cairn.info/revue-de-l-ofce-2020-2-page-59.htm

QUIBB (2011). The QUIBB Survey "Questionnaire of Basic Indicators of Well-Being”, QUIBB Report 2011/UNDP in Togo.

QUIBB (2015). The QUIBB Survey "Questionnaire of Basic Indicators of Well-Being”, QUIBB Report 2015/UNDP in Togo.

RGPH (2010). General Population and Housing Census in Togo, Togo First/Invest in Togo, 2010.

Siddiqui, S. (2020). COVID-19 Lockdown to Leave People Jobless, Businesses Closed in Pakistan. The Express Tribune.

Superior Council of Employment/SCE (2020). State of the Labor Market in Belgium and in the Regions in the Context of COVID-19. http://cse.belgique.be

Taubenberger, J. K., \& Morens, D. M. (2006). 1918 Influenza: The Mother of All Pandemics. Emerging Infectious Diseases, 12, 15-22.

https://doi.org/10.3201/eid1201.050979

The New Economist (2020). What the Economic History of Pandemics Teach Us, December, 2020.

http://https//www.lenouveleconomist.fr/ce-que-l-histoire-economique-des-pandemiesnousapprend-76679/ 
Togolese Republic (2006). Loi No2006-portant code du travail. Lomé.

UNAIDS (2002). Business Responses to HIV/AIDS: Impact and Lessons Learned. Geneva.

UNAIDS (2020). Fact Sheet 2020-Latest Statistics on the State of the AIDS Epidemic. Geneva.

UNCTAD, United Nations Conference on Trade and Development (2020a). The Covid-19 Shock to Developing Countries: Towards a "Whatever It Takes" Programme for the Two-Thirds of the World's Population Being Left Behind.

UNCTAD, United Nations Conference on Trade and Development (2020b). Investment Trends Monitor: Impact of the Coronavirus Outbreak on Global FDI. https://unctad.org/en/PublicationsLibrary/diaeinf2020d2_en.pdf?user=1653

UNDP (2014). The Socio-Economic Impact of Ebola Virus Disease in Guinea, Liberia, and Sierra Leone. Policy briefs \#1-5, 1.

UNDP (2020). Analysis of the Impacts of the COVID-19 Pandemic on the Economy and Socio-Economic Conditions of Vulnerable Households and Groups. Togo.

WAEMU (2020). Semi-Annual Report on the Implementation of Multilateral Surveillance.

WAEMU Regional Consular Chamber (2020). COVID-19 Report: Impact of the COVID-19 Pandemic on the Private Sector in the WAEMU.

WB (2020a). Togo Economic Situation Report: Boosting Private Investment for More Growth and Jobs. Washington DC: World Bank.

WB (2020b). Poverty and Shared Prosperity Report 2020: Reversals of Fortune. Washington DC: World Bank.

WDI (2020). World Economic Situation Prospects, United Nations.

Word Economic (2020). The Global Economic Outlook During the COVID-19 Pandemic: A Changed World, the World Bank, 2020. 